\title{
A rettenthetetlen kiflivég-saga
}

\author{
Keresztesi József: Csücsök, avagy a nagy \\ pudinghajsza (Rajzolta: Horváth Ildi)
}

\author{
Baka L. Patrik \\ Selye János Egyetem, Tanárképző Kar Magyar Nyelv és Irodalom Tanszék
}

\begin{abstract}
Absztrakt
Jelen tanulmány Keresztesi József Csücsök, avagy a nagy pudinghajsza című verses meseregényét állítja fókuszba. A munka első szakasza a modern- és a kortárs meseregények sajátosságai, különbségei és eredői felől közelít a műhöz, majd rátér Keresztesi mesevilágának narratopoétikai jellegzetességeire, kiépülésére, határaira és határátlépéseire. Részletesen elemezzük az alkotás formai jellemzőit, nyelvének egyszerre kortárs és archaizáló vonásait, az egész művet átszövő humort, a világjelleget híven tükröző poétikát és névadási stratégiát, de kitérünk az önreflexiókra, az intertextuális kapcsolódásokra, valamint érintjük kép- és szöveg viszonyát is a kötetben.
\end{abstract}

Kulcsszavak: verses meseregény, formaelemzés, tipizálás, humor, önreflexiók

„Lejjebb pedig széles vigyorba Fut át a hetyke kifliszájNem is rossz Végső Szalmaszál...” (Keresztesi, 2018, p. 23)

Vannak azok a történetek, amelyeket nem lehet elégszer újramesélni. Éppígy nem szükségszerűen hátrány az sem, ha már a második fejezetet olvasva sejtjük a saga végét. Bizonyos szövegcsoportokon belül a narratíva olykor egy szertartás kanonizált, láncszemekként egymásba kapcsolódó stációira hajaz, ahol az szülne hiányérzetet, ha kiiktatódna egy-egy elem. Annak ellenére azonban, hogy egy meseregény nem kíván módosítani a mesei zárt, belső szabályrendszeren és struktúrán, a megöröklött szerepkörökön és azok funkcióin, s még kevésbé a mesebeli etikán, egy újszerü forma és radikálisan módosult, átépített és újrafestett világháttér egyszerre aktualizálhatja s teheti ismét messzemenően érdekessé az adott szüzsét. 
Jelen tanulmány Keresztesi József Csücsök, avagy a nagy pudinghajsza (Keresztesi, 2018)1 címủ verses meseregényét állítja fókuszba, amely az imént körülhatárolt típus mintapéldája. A munka kezdeti szakasza a modern- és a kortárs meseregények sajátosságai, különbségei és eredői felől közelít a választott mühöz, majd rátér Keresztesi mesevilágának narratopoétikai jellegzetességeire, kiépülésére, határaira és határátlépéseire. Részletesen elemezzük az alkotás formai jellemzőit, müködtetett nyelvének egyszerre kortárs és archaizáló vonásait, az egész művet átszövő humort, a világjelleget híven tükröző poétikát és névadási stratégiát, de kitérünk a hangsúlyos szerzői és alkotásönreflexiókra, az intertextuális kapcsolódásokra, valamint érintjük a kötetben szereplő képek és szöveg viszonyát .

\section{Meseregény-tipológia}

Amennyiben a regényre mint korunk legjellemzőbb műfajára tekintünk, a meseregény a mese korszerüsítésének mondható, és a gyermekirodalmi korpusznak is egyik legmeghatározóbb szeletét adja. Amint azt a Jelen idejü holnemvolt hasábjain Lovász Andrea megállapítja (vö. Lovász, 2007), a mesei szerkezet viszonylatában a meseregény terjedelmileg nagyobb ívü lesz, ami magával hozza a mesei elemek és motívumok halmozását, valamint újak létrehívását is. Bárdos József ezzel összhangban jegyzi, hogy a meseregényt a regényhez mindenekelőtt terjedelmi sajátosságai és cselekményének szövevényessége kapcsolja, szereplői, tipikus motívumai és mozzanatai azonban inkább a meséhez kötik (Bárdos, 2013b, p. 69). A nyelvet a szerzői stílus határozza meg - ennek okán jóval szubjektívabb mint a népmeséknél -, amelyet nagyban befolyásol a megírás korának nyelvhasználata, különös tekintettel a gyerek- és kamasznyelvre, valamint a szlengre. Az irodalmi mesékhez hasonlóan meghatározó a humor szerepe, a különféle nyelvi regiszterek keverése (hétköznapi vs. irodalmi, gyermek vs. felnőtt, szleng vs. archaizmusok), a paradoxonok (emelkedett vs. profán egymásmellettisége), az abszurd ötletek és az intertextuális kapcsolatok építése (Petres Csizmadia, 2015b, p. 213). A központi figurák - akik nagy arányban gyermek-/gyermeki szereplők - motivációi itt általában kevésbé sematikusak, a jellemük árnyaltabb, az önmegvalósítás helyett pedig inkább a másik, a család vagy épp az egész világ megmentése kerül(het) fókuszba. A világháttér sokszor kilép az idealizált, mitikus középkort idéző mesei keretek közül (vö. Jeney, 2017), és inkább lesz aktualizált. A természetfölötti kiemelt jelentőségű marad, sőt, a múlt század végi modern művek viszonylatában manapság még jelentősebb. A meseregényeket jellemzi a valóság és fikció versenye, az „ideát” és az „odaát”, tehát (legalább) két dimenzió párhuzamos jelenléte, amelyek között az átjárás viszont sokszor csak a (kiválasztott) (gyerek) szereplők számára lehetséges. Mindezen túl alapvető elvárásnak tekinthető a folytonos feszültségkeltés, a hősök lelkiállapotának hangsúlyosabb ábrázolá-

${ }^{1}$ A tanulmányban használt utalások oldalszámai a könyv 2018-as kiadására vonatkoznak. 
sa, valamint a világ $\mathrm{s}$ az azt felépítő elemek tömörsége, feszes összetartozása (Lovász, 2007, p. 85). Mindeme jellemzők úgy körvonalazzák a szövegtípust, hogy egyszersmind Keresztesi taglalt művét is leírhatjuk velük. Eltérést csak a szereplők tekintetében figyelhetünk meg, a Csücsök animált - lélekkel ellátott - hősei ugyanis inkább maradnak meg a tiszta, népmesei típuskarakterek szintjén, s különösebben a lelkiviláguk sem tárul fel.

Bárdos József $A$ meseregény müfaji sajátosságai címü kötet fejezetében a mesére jellemző hét alapvető ismérv mentén állít egymás mellé neves meseregényeket - a müfaj első képviselőjének tartott Pinokkiótól kezdve az Ózon át a Harry Potterig -, melyek mesei erősségét így az egyes szempontok érvényre jutása határozza meg (Bárdos, 2013b, p. 71). A Csücsök nem szerepel az adott listán - ez már csak keltezési éve okán sem lehetséges -, ezért az egyes megközelítési pontokat úgy sorakoztatjuk fel, hogy közöljük a müben való érvényesülésüket (+) vagy annak hiányát (-) is: csoda (-), mesei téridö, tehát meghatározhatatlan helyszín és idősík (+), mesei hős (+), a fóhős jellemének állandósága $(+)$, mesei gonosz/ellenség $(+)$, bipoláris tér, tehát csakis a jó és a rossz oldalhoz tartozó szereplők jelenléte a müben (-), valamint a jók diadala, azaz az eukatasztrófa (+). A kétpólusú tér azért nem érvényesül, mert vannak állást nem foglaló szereplőink is, érdekesebb viszont a csoda, azaz a varázslat hiányának ténye, ami annak ellenére is igaz, hogy „[a] könyvben a gasztronómia találkozik a mesék fantáziavilágával[,] [...] [a] szerző [pedig] emberi tulajdonságokkal ruházza fel a cukrásztermékeket, miközben színes, kalandos mesevilágba vezet be minket. Lépten-nyomon belefutunk valami finomságba, így olvasó legyen a talpán, akinek nem fut össze a nyál a szájában" (Várkonyi, 2018). A bárdosi szempontrendszer kapott eredményéből jól látható (5+ vs. 2-), hogy a Csücsök igen közel áll a mesék világához.

A fentiek fényében Keresztesi meseregénye Boldizsár Ildikó tipológiája szerint - amely az irodalmi meséket és meseregényeket komparatív módon veti össze a népmesékkel, az azoktól való eltávolodást és adaptációjuk módját egyfajta lépcsőzetes skálaként fogva fel - a helyettesitett és inverz (tündér) mese (Boldizsár, 1997, p. 196) típusába sorolható. Ennek jellemzője, hogy úgy tartja meg a (tündér)mesei elemek, motívumok, cselekedetek legjavát, hogy szabadon variálja azokat, módosítja kivitelezésüket, de mindezt szerepük, feladatuk megtartásával. A változások alapvetően a mese csodás részeit és a szereplők funkcióját érintik. Előbbiek mindinkább háttérbe szorulnak, utóbbiak helyét pedig hétköznapi emberek, gyerekek, animált állatok és tárgyak vehetik át. A típus a gyermekbefogadóval (is) számol, ezért a szöveg sokszor békaperspektívát vesz fel, és - mint alább látni fogjuk - a megcélzott korcsoport nyelvének sajátosságait ölti magára.

Fontos hangsúlyozni, hogy Keresztesi szereplői, annak ellenére, hogy animált tárgyak, nem varázsolnak és nem is szembesülnek csodával, ilyenformán ez a jellegzetesség egyfajta szakadékot teremt köztük és a klasszikus tündérmesék közt - a típus "tündér-” előtagját ezért is zárójeleztük az előző bekezdésben -, amit viszont a fantasztikus világ kiépülése áthidal. A Csücsök maradéktalanul 
eleget tesz a tündérmesék V. J. Propp által meghatározott alap funkciósorának is, mely a következőképp szerveződik: a világ rendjének megbontása hiányfelismerés, veszteség által (Vérpuding elrabolja Csokisminyon királykisasszonyt) » $a$ hös útnak indul (Csücsök elhagyja Tortavárat) » találkozás az adományozóval/segítővel (Csücsök találkozása Vattacukorral/Csárlival és Marcipánegérrel) » újabb helyváltoztatás (át a Rengetegen és a Fondán-folyón) » összecsapás az ellenféllel (csoportos küzdelem Vérpudinggal) » az álhősök leleplezése - sorrendcserével, ez a pont Keresztesinél még a tényleges hős útnak indulása előtt bekövetkezik (a Csokisminyon kiszabadítására indult, jelesebbnél jelesebb süteményhad tagjainak eltűnése/bukása) » gyözelem (Csücsök házassága Csokisminyonnal) (vö. Propp, 1995). Az ugyancsak Propp által körvonalazott tündérmesei szerepköröknek (vö. Propp, 1995) éppúgy megfeleltethetők Keresztesi József figurái: hős (Csücsök), útnak indító (Császármorzsa), segitootárs (Csárli, Marcipánegér, papagáj), adományozó (Vattacukor), ellenfél (Vérpuding), álhős (a „Pompázó Habcsók-hercegek" [18]) és a királylány (Csokisminyon). Mindezen ismérvek hathatósan igazolják, hogy Keresztesi munkája a fantasztikumtól a kalandos történet felé haladó, Lovász Andrea által meghatározott skálán cselekményessége mellett is az előbbihez áll közelebb, hiszen a proppi (tündér)mesei szerkezet hü követésével meglehetősen hagyománytartónak számít (Lovász, 2007, p. 99). Ez az eredmény összecseng a bárdosi pontrendszernél tapasztaltakkal, $\mathrm{s}$ a szerző állításával is, miszerint „egy meglehetősen egyszerü alaptörténetet egészítek ki abszurd elemekkel" (Kránicz, 2018).

A meseregény szerkezetének feszességét tekintve Bárdos József három típust, a füzéres, az egy cselekményszálra felfüzött valamint a valódi meseregényeket különbözteti meg (vö. Bárdos, 2013b, p. 72). A Csücsök ezek közül leginkább az egy cselekményszálra felfüzöttek korpuszát gazdagítja, amely bár a füzéreshez hasonlóan epizódokra bomlik, vele ellentétben itt a fejezetek sorrendje kötött, hiszen a cselekmény fokozatosan halad elöre a szakaszok egymásra épülése során - valamilyen módon mind a végkifejlet felé mutat, minden tett a cél elérését szolgálja. A típus tulajdonságai közül érvényes a karakterek relatíve statikus jellege - azok fejlődésére leginkább a valódi meseregények kínálnak példát -, hiszen már a bemutatkozásukkor rendelkeznek azokkal a tulajdonságokkal, amelyek révén betölthetik funkciójukat. A szöveg bátran ajánlható már kisiskolás kortól, azzal a kitétellel, hogy az intertextuális és intermediális megoldások egy részét csak a tinédzserek, illetve a felnőtt olvasók fedezik majd fel. Utóbbi a mű duplafedeles jellegét erősíti, amennyiben „a befogadó a maga számára annyit képes elsajátítani, amennyire a műveltsége, az életkora, a pillanatnyi helyzete és hangulata képessé teszi" (Bárdos, 2013a, p. 16).

A Csücsök a szüzsé és a szöveg funkciójából kiinduló, Petres Csizmadia Gabriella által meghatározott típusok közül mindenekelőtt a kaland-meseregények korpuszába sorolható (Petres Csizmadia, 2015a), hiszen a mủ centrumában az a kaland- és akadálysorozat áll, melyet - első ránézésre jellegtelen és jelentéktelen, a megrajzolt világháttérből és társadalomból is legalább részlegesen kilógó - hősünk abszolvál, bizonyítva rátermettségét. 
Kiss Judit a meseregényekben kiépülő csodás világot, valamint az ott szerzett tapasztalatokat egy olyan önmagába forduló cselekményminta derékhadaként prezentálja, mely szerint a főhős előbb bár elvágyódik a valóságtól, végül mégis oda tér vissza (Kiss, 2008, p. 58). Ez a mozgás Keresztesi művére is érvényes, de különös módon úgy, hogy nem a főhős, hanem a segítőként feltűnő papagáj, illetve annak gazdája, a narrátor révén megy végbe. Noha a megverselt kalandok számukra is izgalmasak lehetnek, sem jellemük kiteljesedéséhez, sem a fantáziavilág megtagadásához, de az ott átéltekkel s a különleges környezettel szembeni ellenszegülésükhöz sem járulnak hozzá, melyek a szakíró mintázatának potenciális végöltései. Megjegyezhetjük továbbá, hogy a Kiss által elemzett ciklus a népmesékre jellemző kezdő- és záróformula lenyomata is egyben, amennyiben azok is a valóságtól való eltávolodást (például „Az Óperenciás-tengeren is túl...”), majd az oda való visszatérést (például „Én is ott jártam, ittam-vigadtam az esküvőjükön, és onnan hoztam Nektek ezt a mesét.") is hivatottak voltak jelölni (Andrásfalvy et al., 2001, p. 23). Az irodalmi mese és a meseregény előszeretettel hagyja el, vagy alakítja át ezeket a formulákat, ahogy Keresztesi is, aki a papagáj röpte révén él egy alternatív, kvázi egymásra kapcsolható kezdő- és záróformula-duóval:

"Eltűnt a sárga papagájom. / Kiszállt a konyhaablakon. / Azóta sajna nem találom: / Ki tudja, merre jár vajon? [...] Vidám volnék, elégedett, / A szívem könnyü, s azt remélem, / Hogy nemsokára hazaszáll / Hozzám a sárga papagáj." (2018, p. 3, 93).

Nem mellesleg a papagáj a kibillentője az önfeledt, boldog befejezésnek - az eukatasztrófának - is, ami a népmesék s az irodalmi mesék legjavának is alapvető követelménye, hiszen azt nem szögezi le a szöveg, hogy a madár végül visszatért volna gazdájához. Ilyenformán a zárlat a valósághoz közelebb álló narrátori szinten inkább marad meg csupán reménytelinek, mintsem boldognak.

A szakirodalom a kortárs mese- és ifjúsági regények általános ismérveként tartja számon a fantasztikum és az életszerűség párhuzamos felerősödését, $\mathrm{s}$ azt, hogy a modernekkel szemben az „idealizált, tökéletes világábrázolás helyett tabumentesen közvetíti[k] tapasztalatai[ka]t" (Petres Csizmadia, 2015a, p. 200.), az élet árnyoldalai felett sem hunyva szemet. A markánsabb tematikai változások közül azonban, mint amilyen az antiautoriter-jelleg, a krízishelyzetekkel való életszerű szembesülés, a metafizikai, erkölcsfilozófiai kérdésfelvetések vagy a zöld-jelleg, Keresztesinél eggyel sem találkozunk. A bánat taglalása (p. 17, .21), Csücsök lekicsinylése (p. 22-23), sőt még az egyedül húsalapú animált föellenség is ezek nyomainak tünhetnek, a jelzett új problémakörök ilyen arányban azonban a modern meseregényeknél is jelen voltak. Szereplők tekintetében a hős bár korántsem tekinthető idealizált hérosznak, cselekedetei motivációjaként a klasszikus párkeresés tünik fel, s - nyilvánvaló animáltságán túl - ezért sem tekinthetünk rá gyermekszereplőként. Más viszont a helyzet a nyelvhasználat tekintetében, hiszen hathatósan jelen van a nyelvi rétegek ke- 
verése - az olykor archaizáló irodalmié és a kortárs diákszlengé -, a humor, a szöveggel való játék, az intertextuális kapcsolódások, a nyelvjáték, s részben a müfaji hibridizáció is, amennyiben a mesei struktúrán alapuló kalandregény egy-egy ponton gyerekhorrorba csap át. A narrátor - aki úgy homodiegetikus, egyes szám első személyü, hogy a történet tekintetében omnipotens is - által használt monologikus formát meg-megszakítják az egyes szereplők felszólalásai, de legalább ilyen gyakran a maga önreflexiói is, például saját élményeire, ízlésére, véleményére vagy épp az írásfolyamatra vonatkozóan. Maga viszont nem helyezkedik gyermekszerepbe, jóllehet, az odaértett olvasója kétségkívül az, ezért a beszédmódja is hozzá idomul (vö. Petres Csizmadia, 2015a, p. 201).

Összegzésként tehát kijelenthetjük, hogy a Csücsök, avagy a nagy pudinghajsza fóként poétikai tekintetben hordozza magán a kortárs meseregény sajátosságait, karakterrajzai, proppi cselekményszerkezete és világlátása inkább a modern meseregény, sőt, a népmese hagyományait idézik.

\section{Sütivilág-építés}

A könyvbéli mesélés folyamata voltaképpen egy paradoxonból bontakozik ki, hisz amíg a narrátorunk épp azon kesereg, hogy megszökött a sárga papagája, $\mathrm{s}$ „[m]ár húzza is a csíkot el” (p. 3), mi úgy követjük végig a madár útját, hogy közben az elbeszélői hang is megmarad. Mindebből rögtön arra következtethetünk, hogy a mesélő feltételezésekbe bocsátkozik.

Amint Tamkó Sirató Károly Tengerecki Pálja valós és fiktív tereket ró, a nyelv teremtő ereje által egyikből a másikba csúszva át, a mủ szerint úgy szállhat (sic!) a papagáj is mind a négy égtáj felé. Rá a gibraltári szirtfokra, szemrevételezheti a norvég bőregereket, a finn kökénynyalókákat, a répasörrel koccintó Hóembereket vagy akár tudatosíthatja, hogy az Újvilág és India nem egy irányban van. Aztán a valós hirtelen elmarad, és a „térkép másik oldalán” (p. 8), Elrejtett Országokban, párhuzamos világokban találjuk magukat, amiket a mű olyan ötletekkel jellemez, melyekből újabb köteteket lehetne kibontani, s melyek poétikája már ekkor elörejelzi a meseregény nyelvet és ok-okozatiságot kifordító, nonszensz gondolkodásmódját.

"Ám vannak távolibb világok, / Van sok-sok titkos tartomány - / A térképen nem találod, / Mert elrejtőzik mindahány. / Hírét se hallod az országnak, / Hová a Kóbor Lufik szállnak, [...] Nem ismerős a Nyamnya völgye, / Ott Nyámnyilák vad törzse vár / (Megtévesztő név, nemdebár, / Hisz nyámnyilaznak nyakra-före), / Sem a Boldog Krumplik Hona, / Hol szirmot hajt a burgonya." (p. 6, 8).

A konkrét kalandra is e világok egyikében lelünk, számunkra most mégis a narrátor azon mérvadó önreflexiói lesznek fontosak, melyeket a már „odaát” játszódó második fejezet nyitányán olvashatunk, a mesélésre mint cselekvésfolyamatra, és saját kvázi-étkezésére vonatkozóan: 
Hát akkor... Hol is hagytam abba? / Elnézést e kis szünetért, / De bevallom, a gondolatra, / Hogy végre Sütiföldre ért / Mesémnek útja nagy sokára, / Összefutott a nyál a számba', / Hát hamm, lecsúszott egy falat - / Bekaptam semmi perc alatt / Abból a kis diós kalácsból, / Melyet családom meghagyott, / Egy falatkát, de jó nagyot, / És most aztán a folytatásról / Nyugodtan eltöprenghetek. / - - - Hol is tartottam, bikficek? (2018, p. 11).

A Csücsök e szöveghelye - számtalan más, a narrátor eseményeket értékelő vagy a szereplőket ösztökélő hozzászólásával megtámogatva - két világszintet feltételez: az elbeszélőét és a rettenthetetlen kiflivég-sagáét. Az előbbi első ránézésre fölérendeltje a másiknak, hisz ő mesél és kommentál - vagy pedig teremt. A mesélés-folyamat mintha az elbeszélő egyéb cselekvései által inspirálódna: az iménti diós kalács elfogyasztása után a sütiföldi Ősi Testőrgárda tagjainak, azaz a Diós Kalácsok, valamint a Vérpuding Vad Éjjelén bekövetkezett kudarcuk ecsetelésére tér rá, ami végül Csokisminyon elrablásához vezetett.

Egy másik idevágó rész, a hetedik fejezet nyitánya Irénkére, az elbeszélő nénikéjére és annak nem épp mesteri cukrászművészetére fókuszál, kinek termékei aztán hirtelen, egyik verssorról a másikra a Csücsök-kaland Rémsütijeivé lépnek elő, és épülnek be a világba:

A Rémsütik kapcsán evégett / Két törzset ismerünk tehát - / A Szétfolyó s az Odaégett / Két törzs, ámbátor egy család. / Hisz ősanyjuk Irénke néni, / Ki hogyha már megunta nézni / Az érintetlen készletet, / Kidobta, s újat készített. / A Sértett Sütemények népe / Hát dúlva-fúlva útra kelt, / Elvándorolt, új honra lelt: / A nagy Fondán-folyam vidéke / Kellőképpen lehangoló - / Úgy döntöttek, nekik való. (2018, p. 58).

A Rémsütik karmai közül végül - akik egyébként nem is annyira elfogyasztani, mint inkább maguk közé fogadni kívánnák Csücsököt, mondván: „Ne félj, haver, hisz jómagad / Ugyancsak furcsa forma vagy - / Tekintsük egymást rokonoknak! / Letört kis kripli-kiflivég, / Jöjj hát, nosza, és állj közénk!" (2018, p. 62) - a szöveg elején elkóborolt papagáj szabadítja ki, egyfajta alternatív deus ex machina-mentőakcióval.

A Diós Kalácsok, a Rémsütik és a sárga papagáj is jól igazolják, hogy a két világ hat egymásra, sőt, Csücsök dimenziója kis túlzással a narrátor étkezéstapasztalatai mentén látszik felépülni - ötletszinten mindenképp. Ezt erősíti Irénke néni is, aki a hivatkozott szakaszon és az Epilógusban éppúgy „Józsikámnak" szólítja az elbeszélőt, mely megoldás belebegteti azt a lehetséges olvasatot, hogy a mü szerzőjét annak elbeszélőjével azonosítsuk.

Az elbeszélő szintjének ekként körvonalazott fölérendeltsége azonban nem marad végig érvényben, a záró szakaszban ugyanis ő is résztvevője lesz a lakodalomnak: állítása szerint maga is ott hallotta a történetet, amelyet aztán megverselt (vö. 2018, p. 92-93). Kérdezhetnénk persze, hogy mégis hogyan, ha a mesét a saját cselekvései, azokból fogant ötletei vagy fikciói dinamizálják, amiként azt is 
csak feltételezni tudta, hogy merre szállhatott a papagája? Nos, a kérdésre nincs egyértelmű válasz, hisz ebben az eldönthetetlen oda-vissza játékban, dimenzióversenyben rejlik a könyv mesés paradoxonja - vagy egy profánabb olvasat szerint az elbeszélő megbízhatatlansága, kinek müködése akár egy szimpla müfaji követelmény betartásáért tett törekvésként is magyarázható ${ }^{2}$.

A narrátor folytonos kiszólásai a „bikficekhez”, az odaértett olvasóhoz továbbá egy vele azonos szinten lévő partnert - bennünket - is feltételeznek, aki várja a mesét. $\mathrm{S}$ hogy mi van akkor, ha a kötet elhintett ajánlásait megfogadva végül felolvassuk a történetet? Nos, az élőbeszédet imitáló, számos közbeékelt elbeszélői önreflexió és kiszólás által lehetőség nyílik a mesélés aktusának újrateremtésére, ami a proppi szerkezet és az újraszínezett világ tükrében egy ismert szüzsé aktualizált darabját eredményezi, annak mégis eredeti, ősi létmódjához, az oralitáshoz térve vissza ${ }^{3}$. Igaz, mindezt csak a müködtethető korlátok között - a teljességhez egy elszökött papagáj, egy diós kalácsból álló lakoma és persze Irénke néni is szükségeltetne.

A modern meseregényt jellemző példázatosság leginkább a föszereplő és a föellenség tekintetében érvényesül. Noha mind animált lények, Sütiország evidens lakói magától értetődően a sütemények. Amíg viszont a rendbontó, főgonosz Vérpuding a pudingformába öntött véreshurka lélekkel ellátott alakja, Csücsök egy kisgyermek által megcsócsált kiflivégből avanzsált föhőssé, egyszerre humoros és profán körülmények között:

"Egy kósza kifli tartozéka, / A büszke csücske voltam én, / Ám egy napon egy randa béka, / Egy Kétfogú, Otromba Lény: / Egy Négykézlábú Bébigyermek [...] Egész nap rajtam nyammogott... / Azt hittem: ez lesz mindörökre: / Eláztatott a bébinyál, / De hát egy kifli nem rinyál, / S hogy ott maradtam földre köpve, / Így szóltam: lépjünk hát tovább: / Hisz vár a tágas nagyvilág!” (2018, p. 24).

Amellett, hogy a szakasz retorikai és képi megoldásai jól tükrözik a meseregény nyelvi tabusértéseinek jellegét, dehonesztáló profanitásuk egyszersmind a főhős hétköznapiságának túlzó hangsúlyozása is. Vérpuding jellemző tulajdonságai közt a büzös leheletet, valamint a gyermekbefogadó által túlnyomórészt hevesen elutasított fözelékimádatot tünteti fel („A sárga, zöld vagy barna lé / Csorgott az állán százfelé." [2018, p. 68]), ami megmosolyogtató módja a karakterrel szembeni ellenérzés kialakításának. Ami viszont közös Csücsökben és Vérpudingban, hogy mindketten radikálisan különböznek a sütiktől, s ezáltal a normától is. A mese egyik tanulsága lehet, hogy a rendet megbontó

2 „Alapvetően olyan mesét akartam írni, ami egyben verses regény is, tehát megfelel a verses regény műfaji követelményeinek. És hát ebben a műfajban a történet mesélője maga is belép az események terébe, bele-belekotyog, elveszti a fonalat vagy éppen eltereli a szót. Ezeket a részeket igyekeztem úgy kanyarítani, hogy dupla fenekủek legyenek, így a felnőtt olvasók előtt voltaképpen egy clown-figura szólaljon meg" (Gökhan, 2018).

${ }^{3}$ Az élőszóbeli mesélést jellemző változékonyság esztétikájának ismérvei kapcsán lásd: Andrásfaly et al., (2001). 
szélsőség csak egy másik kívülálló segítségével lesz felszámolható, ami együtt jár a korábban lenézett, kinevetett elfogadásával és felemelkedésével is. Amiként azt az idézet messzemenően pozitív végkicsengése is sugallja: a legjelentéktelenebb előtt is nyitva áll a hőssé válás útja. A népmesei szegény legény pozícióját elfoglaló rettenthetetlen kiflivég is így nyeri el végül a maga királylányát, s hozzá természetesen egy fél királyságot is.

Érdekes karakterek még a szószátyár Aszalt Meggy Csárli és a Vadonban Robin Hood-ként feltűnő Marcipánegér. Előbbi animáltsága talán a Csücsökénél is jelentéktelenebb, hiszen Császármorzsa halászta elő tejszínhabkoronájából, hogy a kiflivég útitársa legyen. Marcipánegér a testhatár-eltolásai kapcsán érdekes, hiszen az orrát jelentő rágót egyszerűen elveszíti - pontosabban a rárontó Bundáskenyér kaparintja meg tőle és rágja aztán a végtelenségig -, amit viszont hamar egy „Újragondolt Orrgolyóval” helyettesít: Csárlival. E két karakter viszonya is remek példa a mü nonszensz jellegének igazolására.

Keresztesi végig a játékra, a szórakoztatásra koncentrál, sehol nem müködtet direkt didaktikusságot, ez azonban nem jelenti azt, hogy egyfajta háttérzöngeként ne lennének a sorok közül kiolvashatók bizonyos életigazságok és tanulságok. Az első ilyen a Tortavárra telepedő bánat sötét madárral való azonosítása, s hogy „Az undok dög nem rebben el, / Lecövekel, onnan figyel” (2018, p. 21) mindaddig, amíg Csücsök el nem hozza a reményt. A szöveg viszont nem a tétlen várakozásra, hanem a cselekvésre biztatja Császármorzsát, hogy ha kell, hirdessen „pályázatot”, amivel a merész sütilovagokat magához hívhatja. „Hát kiálts rá, és kergesd messze! / Koppints rá görbe csőrire! / Elszánt, kemény hang kell ide" (2018, p. 17) - olvashatjuk, tanulságaként annak, hogy mindenkori helyzetünk és lelkiállapotunk, vagy annak megváltoztatása részben mindig rajtunk áll.

Nyomokban jelen van egyfajta multikulturalizmus is, amennyiben az érkező „tejszínhabhuszárok” (2018, p. 14) között Sir BonBon éppúgy ott van, ahogy Möszjő Franciakrémes vagy épp a Bátor Baklavák is. Mindez azt is jelzi talán, hogy amiként a különféle népek gasztronómiájának termékei békésen megférnek egymás mellett mindennapi étlapunkon, s mi magunk sem aszerint idegenkedünk egyiktől vagy másiktól, hogy melyik tájegységről való - hanem az íze, pardon, a jelleme szerint -, úgy ez lehetne az irányadó az egyes etnikumok egymás mellett élésében is.

Csokisminyon királykisasszony rabságának ecsetelésekor Vérpuding erődjében a következő napi rutinról olvashatunk: „A rücskös kőpadlót sikálja, / Mos, fóz, vasal, rosszkedvű rab" (2018, p. 68), mely szakasz a sokszor elbagatellizált és szexista módon csak női házimunkaként számon tartott tevékenységekre reflektál. S mivel e "munkamegosztást” a szöveg a fögonosz sziklavárában teljesíti ki, gyakorlatilag rabszolgamunkának nevezve azt, megítélésének és egyáltalán (a szerepek) működésének/leosztásának újragondolására is ösztönöz.

Összegzésként konstatálhatjuk, hogy a Csücsök két világszint, az elbeszélö és a mesehősök dimenziójának versenyeként és összefonódásaként épül fel, ami felolvasva, az elbeszélő önreflexiói révén a mesék orális hagyomá- 
nyát is megidézi. A nonszensz, testhatár-eltolódásokat is felvillantó animált szereplők kalandjai során a sorok között olyan kérdésekkel is szembesül az olvasó, mint a bánat elüzése, a békés egymás mellett élés és a női emancipáció, miközben a mese azt az örökérvényü igazságot visszhangozza, hogy a kitartás a legjelentéktelenebbnek tűnőt is a legmeghatározóbbá teheti.

\section{Meseregény-poétika}

A Csücsök esetében, amiként a világépítést, úgy a formát is végig egyfajta kettősség, a klasszikus és a kortárs megoldások versenye jellemzi. Kétségkívül a klasszikus hagyományokat erősíti, hogy a teljes mü Anyegin-strófában íródott (rímképlete: ababccddeffegg; állandó szótagszáma: 98989988989888), amit az Epilógusban - ugyancsak Irénke nénire hivatkozva - a szöveg maga is jelez, igaz, kellőképp ironikus stílusban:

"A himbilimbi rímeid... / Ajajj... Ne is kinozz. / Nem kell, hogy mindent itt nekem / Így összepuskinozz. / Törd ketté végre tolladat, / És hagyd az éneket! / Kukkants inkább a tepsibe: / Sütöttem én neked..." (2018, p. 94).

Irénke néni véleménye ellenére Keresztesi igazolja: egy klasszikus forma, új tartalommal feltöltve éppúgy működhet élettelien, sőt, a gyermekirodalom tájain is gyümölcsözően honosítható meg. Mészáros Márton szavaival élve, „[a]hhoz azonban, hogy egy ennyire klasszikus müfaj ennyire frissnek tünjön, mint a Csücsök esetében, nem csak Keresztesi József imponáló formabiztonsága, meglepő képzettársításai, a versnyelvre való folyamatos reflexiója, önfeledt humora és játékossága, de a történetvezetés precíz megszerkesztettsége, sőt szigora kellett" (Mészáros, 2019). A jambikus lejtésű mű egésze szinte kizárólag asszonáncokkal dolgozik, az egyes versszakok utolsó rímpárja - az Anyegin-strófához híven - gyakran csattanót tartalmaz ${ }^{4}$ Szavakat szinte sosem vág ketté, s ha mégis, úgy azt menten önreflexió és humor tárgyává teszi:

"Vagy ott a Príma Pókok Földje, / Hol gördeszkán jár Borcsa pók, / Kezében príma légycsapók, / Suhan-robog vele a görde- / szka. (Jó, ez itt egy lüke rím - / Elnézést érte, feleim.)" (2018, p. 7).

Az olyan rímlelemények, mint a „Borcsa pók” és a „légycsapók” összevillanása, tudatosítva, hogy a pókok tekinthetők bolygónk talán legügyesebb légyvadászainak, jól jelzik a szerző nyelvi érzékenységét. Az idézetben szereplő archaizmus, a „feleim” használata ugyancsak figyelemfelkeltő, és egyszers-

\footnotetext{
${ }^{4}$ Amint arról a szerző vall: „a könyv szereplői számomra nem sütemények, hanem szavak, sőt, időnként egyenesen szótagszerkezetek: egy verses regény figurái, akiknek meg kell találni a helyét egy olyan, egyszerre játékos és szigorú struktúrában, mint az Anyegin-strófa. Szótagszám, lejtés, rímszerkezet, és akkor még csak a strófán belül vagyunk; afölött pedig ott az elbeszélés rendje, a hangfekvés, az elbeszélt világ rendje, és így tovább” (Gökhan, 2018).
} 
mind az irónia kacsintással felérő jelölője a „görde-szka” elvágásának, szétcsapásának vonatkozásában. A meseregény mindazonáltal számos archaizmust használ (mint például „nem lelem”, „elnyelé”, „legott”, „botorkálván”, „midőn”), jóllehet, a kortárs gyermeknyelvi szleng (mint például „klafa”, „mentőexpedíció”, „nagyarcok”, „kispofám”, „legós”, „dedós”, „tunkol”, „hajcihő”, „nyúlcipő”) és az elsőrendű mintaolvasóhoz igazított detabuizáló törekvések (mint például „,volt belőlük marhasok”, „dögnehéz”, „drabális”, „bumburnyák”, „bekrepál”, „Büzpofájú” vagy épp a Büffök és Broák országa, a hányás sajátos jelöléseként, ami gyermeki körökben is legalább olyan elterjedt élettapasztalat, amilyen a Kóborló Lufiké) sokkal nagyobb arányban vannak jelen.

A klasszikus eljárásokat idézik továbbá a fejezetek tartalmát összefoglaló alcímek - melyek persze nem minden esetben egyértelműek: például „amelyben nem készül el a répafózelék” (2018, p. 67) vagy „Minden Eddiginél Rémületesebb Fejezet" (2018, p. 51). Az utóbbi alcím, s a korábbi idézetekben szereplő megnevezések jó példák rá, hogy Keresztesi relatíve szabadon kezeli a kis- és nagy kezdőbetűk használatát, amivel Oscar Wilde szecessziós meséinek egy eljárását idézi meg. Ebbe a mintába illeszkedik, hogy az elnevezések a mi valóságunkhoz viszonyítva nála kevéssé statikusak - a szinonim formáik ugyanazzal a jelentéssel bírnak, például Titkos Helyek, Rejtett Országok, Elrejtett Országok, vagy Testőrség, Ösi Testőrgárda, Régi Gárda.

A versszakvégi csattanók mellett a müvet jellemzik a fejezetvégi cliffhangerek is. Ezek közül a legemlékezetesebb kétségkívül az első szakasz zárlatában olvasható - „S hogy miért e csönd, e néma, döbbent: / Majd elmeséli ezeket / A Következő Fejezet” (2018, p. 9) -, amelyet egy lapozást követően aztán le is reagál az új cím: „Második, avagy Következő Fejezet” (2018, p. 11); az utolsó szakaszt leszámítva a mủ nem él többet ezzel a megoldással. A második fejezetben ugyancsak érdekes zárlatot találunk: „Mint véget ér e fejezet, / Hát jó éjszakát, gyerekek...” (2018, p. 16). E rész azon túl, hogy egyértelműen azonosítja a mủ célközönségét, egyszersmind felolvasási módot is javasol: esténként egy fejezetet. Ha megfogadjuk a tanácsát, a verses meseregény - Varró Dániel humoros értékelése szerint „nagyszabású hőseposz" (Varró, 2019) - andalító jambusai bizonyosan kiteljesítik az élményt. A gyermekolvasó/-hallgató kitüntetett pozíciója megjelenik az első szakaszban is, ahol a Vasvilla Lilla néni földrajztanárnő által képviselt felnőttek nem veszik komolyan a „térképen túli”, fantasztikus világokra inkább vevo gyerekek beszámolóit és olykor csak egy legyintéssel, máskor épp karóval jutalmazzák azokat (vö. 2018, p. 7-8). Mindez a taglalt müfaj azon jellemzőjével villan össze, miszerint sokszor csak a gyermek tud átlépni „odaátra”.

A modern, tehát 20. század végi meseregények poétikai sajátosságai közt Komáromi Gabriella (vö. Komáromi, 1999) mindenekelőtt a játékosságot, valamint a nyelvi játékot említi, melyekből az ugyancsak jellemző humoros névadási stratégiák is következnek. E szempontoknak Keresztesi verses meseregénye maradéktalanul megfelel, gondoljunk csak az állandósult szókapcsolatok környezethez igazított kimozdítására (például „Hol még a Madártej 
se jár!” [2018, p. 46], „Ki reszket mint egy tál zselé” [2018, p. 63]), a fel-feltünő alliterációkra (Csücsök csücsül csak [2018, p. 55]), a proppi szerepkörök mellett korábban feltüntetett szereplőnevekre, vagy még inkább a felsorakozó „Habcsók-hercegek” bemutatkozására:

"S ki handzsárját övében hordta, / A marcona Vadalmatorta, / S kinek haragját retteged, / A Zaboskeksz is megjelent. / És jött a böhöm Rigó János / (Én nem nevezném Jancsinak, / Mert egykettőre helyrerak), [...] És jött az elszánt Meggyes Rétes, / Kemény magokkal köpködő, / És jött Möszjö Franciakrémes, / A hétpróbás pudingölő[.]” (2018, p. 18-19).

A névadás nem minden esetben nyelvjáték révén születik, olykor egyszerüen csak a süteménynevek transzponálódnak át szereplőnevekké az ugyancsak műfajjellemző antropomorfizáció során (például Csücsök, Csokisminyon, Vattacukor). Máskor egy tulajdonság szerinti hasonlóság (például Tortavár, hosszú Rétestészta-út, Fondán-folyam), esetleg metonimikus érintkezés (Puszedli papu) teszi az elnevezéseket indokolttá, a humor és a nyelvjáték mégis leginkább a szereplők jellemjegyekkel - mondhatni epitheton ornansokkal - ellátott bemutatkozásakor teljesedik ki. A fenti példákból kiindulva - az egyes szakaszok általunk kurziváltak - Keresztesi mindig a süteményneveket alkotó szóelemek eredeti szófajából (melléknevek, főnevek), vagy azok többértelműségéből indul ki. Így lehet a nyelvjáték alapja a másik jelentés előtérbe állítása (vadalma helyett vadság, zab helyett düh, zabosság), vagy a jelentés kiteljesítése (möszjő mint a franciaság jelölője, Császármorzsánál és Püspökkenyérnél a főnevek státusszá válása, míg az indiánerek törzzsé, a medvecukrok a vadon ragadozóivá lesznek), a forma megkérdőjelezése (a rigójancsi méreteire és erejére alapozva a becézett Jancsit Jánossá alakítja vissza), annak cselekvésben való megjelenítése (magköpködés), vagy az eredő csonkítása, esetleg új forma létrehívása elemkeveréssel (ilyen lehet Vérpuding neve, melynél a véreshurka első tagja marad csak meg, mely a pudinggal párosulva horrorisztikusabb tónust kap, $\mathrm{s}$ a keveredés révén a karakter idegenségét is jelöli). Leszögezhető, hogy ahol csak módjában áll, Keresztesi József beszélőnevekké teszi a süteményneveket.

A mű több helyen jól beazonosítható utalásokkal, sokszor intertextuális átvételekkel fonódik rá a világ- és magyar irodalmi hagyományokra. Ezek közül az egyik legemlékezetesebb a korábban már említett fekete bánatmadárhoz kötődik:

"A mélabú otromba varja / (Vagy holló volna? Csóka tán? / Kócsagnak csak nem mondanám...) / Úgy dönt, hogy mindez nem zavarja: / Tollászkodik a nagy madár, / S nem moccan többé soha már." (2018, p. 21).

A madár hollóval való potenciális azonosítása már elhinti a szövegközi kapcsolás magvait, a versszak csattanóként is érthető utolsó sora pedig kitel- 
jesíti azt a „soha már” befejezéssel, Poe $A$ Holló című versének Tóth Árpád általi fordítását idézve meg. A kapcsolatot tovább erősíti, hogy a madár Keresztesi fejezetében is a veszteség, a bánat és a kilátástalanság jelölője, a megidézett müben szereplőhöz hasonlóan.

Kissé kötetlenebb, ám a kontextus által mégis felerősített a kapcsolódás a negyedik fejezet 12. versszaka („Az túlnan ott a zord Vadon / És vár terád nagyon, nagyon... / Inadba szállt a bátorságod? / Talán nem is való neked: / Veszélyes hely a Rengeteg!" [2018, p. 35]) és Dante Isteni szinjátékának babitsi fordítása, pontosabban a mű második tercinája közt („Ó, szörnyü elbeszélni mi van ottan, / s milyen e sürü, kúsza, vad vadon: / már rágondolva reszketek legottan." [I/3-6]). A mozzanat mind Dante, mind Csücsök számára vízválasztó: az első lépéseket jelenti az ismeretlenbe, az élet és a(z életen túli) veszélyek irányába, melyeket mindkét mü - és még sok más - egy sötét erdő képével tükröz le. Vérpuding elől menekülve, illetve a hazaúton aztán ugyanaz a Rengeteg Keresztesinél elveszti minden fenyegető színét, sőt a biztonságot jelentő hellyé válik. Mindennek egyedüli oka pedig az ismeretlen (fenyegető) ismertté (barátságos) válása, ami a Csücsök egy újabb tanulsága.

Amennyiben a verses meseregények hazai, architextuális öröksége felől tekintünk a Csücsökre, Varró Dániel Túl a Maszat-hegyenjén túl - amellyel az Anyegin-strófa révén is rokonságban áll - a legnevesebb kvázi-elődként bizonyosan Petőfi János vitézét találjuk meg; e kettőre a hátlapszöveg is utal. Petőfi műve erős tündérmesei motívumrendszere mellett azért is evidensebb példa, mert szerzőjére a szöveg is utal:

"Hogy merre járt mint ifjú vándor / (Annyit csavargott, komolyan, / Akár egy őrült kamion) / A zöldfülü Petőfi Sándor: / Hol Kecskemét, hol Debrecen - / Pontosan nem tudom ma sem. [...] De hát Petőfi nem piskóta - / Habár Minyon kisasszonyért, / Ha piskótának szánja sorsa, / Bizonnyal ontott volna vért[.]" (2018, p. 32-33).

A műfaji előd előtti sajátos, kontextushoz és sütivilághoz igazított tisztelgésen túl („Petőfi nem piskóta”) alkotásainak heroikus szóhasználatát éppúgy megidézi („ontott volna vért”), amiként életútjának egy-egy elemét is. Vegyük észre viszont, hogy a „Pontosan nem tudom ma sem” sor pozitivista oktatásrendszerünk kritikája is ${ }^{5}$. Petőfi kapcsán a narrátor fejében keveredő életrajzi adathalmaz nagyobb hangsúllyal van jelen a szakaszban még a műveinél is, ami a sorok között bizonyosan arra ösztökéli a Csücsököt feldolgozó pedagógusokat, hogy újra elgondolkodjanak tantárgyuk fókuszán, vagy legalább az arányokon.

Rövidebb összevillanásokat találunk még Homérosz, Gogol, Tandori és Bereményi Géza műveivel is, amiként egy-egy kulcskifejezés a magyar me-

\footnotetext{
${ }^{5}$ Amikor explicit irodalmi utalásokkal találkozunk, akkor ez a furcsa mesélő hadovál: azt akartam, hogy a megnyilvánulásai a felnőtt olvasót is szórakoztassák (Kránicz, 2018).
} 
seregény-hagyományt is felvillantja - a „tüskevár” (2018, p. 45) Fekete István azonos című művét, a Marcipánegér „krumpliorra” (2018, p. 47) Csukás István Keménykalap és krumpliorrát, míg (a) Vérpuding Bozsik Péter 1999-es verseskötetének címe is egyben. Az úti cél új ismerősöknek való kifejtését két sorban lerendező kommentár - „Nem ismétlem most magam, / Hisz tudjuk, mi járatba' van" [2018, p. 46]) - pedig mintha a klasszikus meseregények, például Baum $O z$, a nagy varázslójának túlzásba vitt ismétléskritikája volna.

Az irodalmi kapcsolásokon túl a mű számos intermediális utalással él. $\mathrm{Az}$ „Ez itt - csak annyit mondanék - / Nem Tésztának való vidék!” (46. o.) megfogalmazás a Coen fivérek világhírü filmjének kvázi állandósult szókapcsolattá lett címét, a Nem vénnek való vidéket idézi meg és billenti ki. Az „E kőtenger oly messze tárul, / A végtelenbe és tovább” (2018, p. 60) szakasz második sora a mára többgenerációssá lett Toy Story-széria egyik főhősének, Buzz Lightyearnak a jelmondatát villantja fel, míg csatahelyzetben Vérpuding használja James Cameron kultikus akció-sci-fijének címét/mechanikus gyilkológép-megnevezését Csücsök lekicsinylésére egy sajátos szópár alkotóelemeként, „Kis tésztaképű terminátor”-nak (81. o.) nevezve őt.

A müfaji hibridizációra leginkább a kötet 48-50., illetve 61-63. oldalain találunk példát, amit intermediális utalások, képzőművészeti- és poétikai megoldások eredményeznek. Horváth Ildi egyszerre gyermekien kedves és kissé bizarr figurái, visszafogott, kontextushoz igazított süteménykrémszínekkel dolgozó rajzai hol egész oldalakat kitöltve, máskor versszakokat körbeölelve, megint máskor csak egy-egy szereplőt - vagy csupán valamely testrészét - és aktuális tevékenységét ábrázolva kísérik végig a szöveget ${ }^{6}$. Tartalmukban a textushoz igazodnak, s annak egyfajta vizualizáló tükreként funkcionálnak. A Vérpuding birodalma felé vezető úton aztán egyre felerősödik a nem tarka színek aránya, hogy a befejezésnél újra az élénkek kerüljenek túlsúlyba ${ }^{7}$. A sötét, horrorisztikus tónusok a Vadonban való éjszakai táborozás során tetőznek („Körös-körül szurokban ázik / A szellő járta Rengeteg” [2018, p. 48]), és a fehér alapon fekete szöveg elosztás is csak itt fordul meg.

Ahogy az a horror(filmek) esti táborozásaihoz dukál, Marcipánegér rémtörténeteket mesél a Fondán-folyó túloldalán bóklászó Rémsütikről, s a Csokoládés Kockasajtról, melynek látványától egy vén Indiáner is elmebajt kapott. A következő versszak a narrátor hitetlenkedő kommentárja, melyben azt bizonygatja, hogy a Csokoládés Kockasajt „idétlen vicc”, „bombasztikus, goromba tréfa csak" (2018, p. 49) - „odaát” nem is találkozunk majd ilyennel, noha tudjuk, a mi valóságunkban létezik. Ezt követően Csücsök rémálmaiba pillanthatunk bele, aki radikális testhatár-eltolásokkal jellemzett keveréksüteményeket, „Pudingpofájú Kockasajtokat”, „Kockaképü Sajtpudingokat”,

${ }^{6}$ A Hintafa felületén olvasható, gyermekbefogadó-fókuszú bemutatószöveg számos vizuális anyagot tesz közzé a müből (palinta77, 2018).

${ }^{7}$ Akad egy-egy zavart keltő megoldás is, például a sárga papagáj sárga csőrét hangsúlyozó versszak mellett feltűnő, kékeszöld-csőrű madár (8. o.), vagy Csárli felidézett - igaz - Távoli Nagynénikéje, akit viszont embernek ábrázolt a művész. 
„Marcipános Vattameggyeket” és „Sajtkalácsokat” (2018, p. 49) lát maga előtt - utóbbi jelölők vizualizálása is igen nehézkes -, mígnem a könyv 6163. oldalain aztán Irénke néni széthulló, félig sült, hörgő, csoszogva „plattyogó”, „bamba-báva” Rémsütijeivel, egy alternatív zombihaddal találjuk szembe magunkat. E mozzanatok mind a horror-müfaj irodalmi és filmes megoldásain alapulnak, de a humorosan játékos hangutánzó szavakkal („plattyanó”), a világ keretei közé illesztett, széteső sütik nevetséges, mesés ábrázolásával elveszik a megidézett zsáner korcsoportidegen élét, s domesztikálják annak eredetileg viszolygást keltő, vizuális megoldásait, a tulajdonképpeni gyerekhorrort teremtve meg. A korábbiak mellett e megoldások is jó igazolói annak, hogy a mű mennyire támaszkodik „az angolszász nonszensz költészeti tradícióra, [amennyiben] az ismert klisék meglepő, és így a felnőtt olvasó számára is élvezhető módon: ironikus fordulatokban tárulnak elénk" (Mészáros, 2019).

Keresztesi József verses meseregénye, a Csücsök, avagy a nagy pudinghaj$s z a$ - amely elnyerte a 2019-es Év Gyerekkönyve Díjat a tizenkét év alattiak kategóriájában (Bookline, 2019) -, eredetileg a szerző Mit eszik a micsoda? címü gyermekverskötetét záró, „vékony” meséből alakult át nagy ívű kalanddá (vö. Kránicz, 2018). A könyv úgy követi a hagyományos tündérmesék struktúráját, hogy közben egy édességekben gazdag sütivilágot hív életre. Úgy használ klasszikus formát, hogy azt a jelen gyerekszlengjével telíti meg. Intertextuálisan és intermediálisan rétegzett utaláshálót müködtet, a gyerekek mellett az idősebbeknek is izgalmas játékot kínálva. Rendkívül önreflexív, nyelvében teremtő és kacagtatóan játékos. Olyan színfoltja a kortárs magyar gyermekirodalomnak, ami nem csak azt éri el, hogy olvasás közben az ember édességre vágyjon, de azt is - és ez sokkal nagyobb eredmény -, hogy a sütikről maga jusson az eszünkbe.

\section{Irodalom}

Andrásfalvy, B., Balassa, I., Égető, M., Gráfik, I., Gunda, B., Kotics, J., Paládi-Kovács, A. \& Petercsák, T. (2001). Magyar néprajz V. A magyar népköltészet. Educatio Társadalmi Szolgáltató Nonprofit Kft. https://www.tankonyvtar.hu/hu/tartalom/ tkt/magyar-neprajz-magyar/adatok.html

Bárdos, J. (2013a). A gyermekirodalom fogalma. In Bárdos, J. \& Galuska, L. P. (Eds.), Fejezetek a gyermekirodalomból (pp. 11-22), Nemzedékek Tudása Tankönyvkiadó Zrt.

Bárdos, J. (2013b). A meseregény müfaji sajátosságai. In Bárdos, J. \& Galuska, L. P. (Eds.), Fejezetek a gyermekirodalomból (pp. 69-79). Nemzedékek Tudása Tankönyvkiadó Zrt.

Boldizsár, I. (1997). Varázslás és fogyókúra. Mesék, mesemondók, motívumok. JAK - Kijárat Kiadó.

Év Gyerekkönyve Díj 2019. Bookline.hu. https://bookline.hu/evgyerekkonyve 
Gökhan, A. (2018). „Hiszen a könyv szereplői számomra nem sütemények...” Interjú Keresztesi Józseffel. 061.hu. https://nullahategy.hu/hiszen-a-konyvszereploi-szamomra-nem-sutemenyek-interju-keresztesi-jozseffel/

Jeney, Z. (2017). A népmese és a mümese határvidékei. In Hansági, Á., Hermann, Z.,

Mészáros, M. \& Szekeres, N. (Eds.), Mesebeszéd (pp. 223-234). FISZ.

Keresztesi, J. (2018). Csücsök, avagy a nagy pudinghajsza. Rajzolta: Horváth Ildi. Móra.

Kiss, J. (2008). Bevezetés a gyermekirodalomba. Ábel Kiadó.

Komáromi, G. (1999). Mesék, regények, gyerektörténetek. In Komáromi, G. (Ed.), Gyermekirodalom (pp. 217-225). Helikon.

Kránicz, B. (2018). „Az irodalom röhögve kibírja” [interjú]. Magyarnarancs.hu. https://magyarnarancs.hu/konyv/az-irodalom-rohogve-kibirja-113419

Lovász, A. (2007). Jelen idejü holnemvolt. Krónika Nova.

Mészáros, M.(2019).AzÉv GyerekkönyvÍrója-2019(12 évalattikategória): Keresztesi József(Csücsök, avagy a nagy pudinghajsza). Mészáros Márton irodalomtörténész laudációja. Móra.hu. https://mora.hu/hir/az-ev-gyerekkonyv-iroja-12-ev-alattikategoria-keresztesi-jozsef-csucsok-avagy-a-nagy-pudinghajsza?utm_camp aign=newsletter_2019_6_25_4\&utm_source=newsletter $\& u$ tm_medium $=$ email\&user_id=7f34fabdd8ea48e

palinta77 (2018). Vidámodjunk könyvekkel az őszbe. Hintafa.blog.hu. https:// hintafa.blog.hu/2018/10/16/konyvekkel_az_oszbe

Petres Csizmadia, G. (2015a). Fejezetek a gyermek- és ifjúsági irodalomból. Nyitrai Konstantin Filozófus Egyetem Közép-európai Tanulmányok Kara.

Petres Csizmadia, G. (2015b). Kortárs irodalmi mesék. Elméleti dilemmák. In Lőrincz Ildikó (Ed.), Teóriák, hipotézisek és az igazság viszonya (pp. 211-217). Nyugat-magyarországi Egyetem, Apáczai Csere János Kar.

Propp, V. J. (1995). A mese morfológiája. Osiris - Századvég.

Várkonyi, Zs. (2018). Ki mondta, hogy egy kiflivégből nem lehet hős? Librarius.hu. https://librarius.hu/2018/09/24/ki-mondta-hogy-egy-kiflivegbol-nem-lehethos/

Varró, D. (2019). Varró Dániel ajánlója. Olvasóvá nevelés, https://olvasovanevels. gportal.hu/gindex.php?pg=37313459\&nid=6811769 


\section{Baka L., P.}

\section{A perspective on modern fairy tales}

The study focuses on the poetic fairy tale of József Keresztesi, Csücsök, avagy a nagy pudinghajsza. The text is first analysed from the perspective of modern fairy tales, followed by an assessment of the specific tools Keresztesi utilises to create his fairytale world. The form of the work is analysed in detail: both its contemporary and archaic linguistic features, its humour and the poetic devices reflecting its strategies of world-building, as well as self-reflexive features, intertextual techniques, and the visual and textual relations of the literary work.

Keywords: poetic fairy tale novel, form analysis, typing, humour, self-reflexive features 